\title{
UNIFORM INTERSTATE ENFORCEMENT OF VESTED RIGHTS
}

\author{
JOHN K. BEACH \\ Supreme Court of Errors of the State of Connecticut
}

Professor Beale divides current doctrine on the conflict of laws into three classes, which necessarily grade into one another: statutory, international, and territorial. Of the last named he says that it

"asserts that no law can exist as such except the law of the land; but that it is a principle of every civilized law that vested rights shall be protected, and therefore that in each country it is sought to find out what rights have arisen anywhere, and to recognize them, applying in all else the law of the land to every question."2

And treating of the historical development of this theory he says:

"Instead of the Dutch theory of comity, the common law has worked out indigenously a theory of vested rights, which serves the same purpose, that is, the desire to reach a just result, and is not subject to the objections which can be urged against the doctrine of comity. ... Story accepted and developed this theory, which from his time has been the accepted theory in the English and American courts."3

And on another page: "The English and American judges have most consistently followed this theory."'

I do not attempt to criticise Professor Beale's classification or definitions, but do dispute his statement that the American courts have adopted the territorial theory of the conflict of laws, instead of the Dutch theory of comity.

The term vested right is used throughout this paper in the limited sense of an existing cause of action for money damages, which would, if prosecuted in the jurisdiction where the cause of action arose, result in a judgment for the plaintiff.

Under any theory of international jurisprudence some vested rights are enforced, and it is possible, therefore, to make a showing in favor of the proposition that Story, for example, was a territorialist, by emphasizing what he says about vested rights and ignoring what he says about comity; and by a like process of selection, that the Supreme

\footnotetext{
"The terms "conflict of laws" and "private international law" are used interchangeably, although the former phrase is in common use in this country in its literal sense as applied to the many cases in which a federal and a state law conflict. See the current indices of U. S. Reports.

I Treatise on the Conflict of Laws, pt. I, p. 63 .

Beale, ro5.

- Beale, ror.
} 
Court has accepted the territorial theory. ${ }^{5}$ Nevertheless, every lawyer knows that in this country some vested rights are, as between the several states, protected by the Federal Constitution; some, when the lex loci and the lex fori are in substantial accord, are enforced upon so-called principles of comity: and others are not enforced at all, for the supposed reason that to do so would violate the public policy of the forum.

I believe that the uniform interstate enforcement of vested rights is bound to come, not only as a matter of justice, but as a logical corollary of the national unity of the several states ; ${ }^{\beta}$ yet $I$ am sure that no useful progress in theory or in practice can be made without recognizing existing conditions; and when Professor Beale says that American courts from the time of Story have consistently accepted the territorial theory as he defines it, he furnishes a justification for a brief statement of what Professor Sumner used to call "the hard facts."

Of course, Story rejected all theories of the automatic extraterritoriality of law, because they were not consistent with AngloAmerican definitions of sovereignty and of law. Nevertheless he accepted the theory then prevalent that the enforcement of a foreign right necessarily involved the extra-territorial operation, within the forum, of the foreign law which created it, and took refuge in the Dutch theory of accounting for the occasional extra-territorial operation of the foreign law as the result of an act of comity on the part of the sovereign in whose court the foreign right was sought to be enforced. His second chapter dealing with "The general maxims of international jurisprudence" is a defense of that theory and not a departure from it; and he sums up his conclusions in the final section of that chapter beginning with the familiar words

"There is then not only no impropriety in the use of the phrase 'comity of nations,' but it is the most appropriate phrase to express the true foundation and extent of the obligation of the laws of one nation within the territories of another."

Surely this is the language of an adherent of the "statutory" theory, which "supposes two independent laws, effective at the same time and

\footnotetext{
- See Mr. Justice Holmes' opinion in Slater v. Mexican Nat. R. R. Co. (1904) 194 U. S. 120, and the dissenting opinion in Hilton v. Gryot (I895) I59 U. S. II3.

- Penal laws do not create private rights: Huntington v. Attrill (1892) I46 U. S. 657 , and as between the several states it is impossible to imagine a "right" based on a transaction abhorrent to generally accepted canons of morality. In some states the rules of procedure may modify the remedy given by the lex loci; and many difficult questions must arise with reference to workmen's compensation acts.

'Story, sec. 38 .
} 
place," and not that of a territorialist. At any rate, such has been the actual influence and effect of his doctrine upon the course of American decisions.

Story's short formula, expressing his distinctive theory of the particular way in which comity operated, was adopted verbatim by the Supreme Court after he became an associate justice:

" 'In the silence of any positive rule, affirming, or denying, or restraining the operation of foreign laws, courts of justice presume the tacit adoption of them by their own government, unless they are repugnant to its policy, or prejudicial to its interests. It is not the comity of the courts, but the comity of the nation which is administered, and ascertained in the same way, and guided by the same reasoning by which all other principles of the municipal law are ascertained and guided." "s

This conception of the wholesale tacit adoption of foreign law, although not infrequently quoted with approval, ${ }^{10}$ never took a strong hold on the judicial or professional imagination of this country. Upon the theory of treating that as done which ought to have been done, it might be possible for courts to assume the tacit adoption of foreign law by a personal sovereign of unlimited powers whose will, no matter how expressed, was law. But it is hard to assume the tacit adoption of law by a modern legislature.

Moreover, the whole process described in Story's formula is one of judicial assumption, and that being so, it was apparent to the courts and the profession that Story was attempting in this particular class of cases to give the color of legislation to the very thing which courts are accustomed to regard as a purely judicial function.

In other words, the attempt was made to cover up the inherent infirmities of the doctrine of comity ${ }^{11}$ by assuming an antecedent

\footnotetext{
${ }^{8}$ Beale, 63:

- Bank of Augusta v. Earle (I839) I3 Peters, 519, 589, citing Story, 37.

${ }^{10}$ B. \& O.R. R. v. Glenn (1867) $28 \mathrm{Md} .287,32 \mathrm{I}$; Thompson v. Waters (1872) 25 Mich. 214, 224; Hysinger v. Supreme Lodge (1890) 42 Mo. App. 627, 637; Gooch v. Faucett (I898) I22 N. C. 270, 273; Commonzealth v. Kuntzmann (1862) $4 \mathrm{I} \mathrm{Pa.} \mathrm{St.} \mathrm{429,} 437$.

in "Comity is a pretext for the evasion of the consequences of a strictly territorial law. After the notion of such a law is denied, it would be idle to combat it, for it becomes unnecessary. But it may not be amiss to observe that in its obscured and little defined concept, interest, courtesy anl reciprocity, ideas so important for the history of law, play a part. In another place we have dealt with these ideas, giving our opinion with respect thereto. The name of science cannot be given to them, nor can a practical and useful system be based upon them. They authorize simply concessions ungoverned by rule, the supposed independence of a state consisting in an adjustment of its conduct to that followed by other states, resulting ultimately in a real isolation between the people of the different countries, and in making of comity and reciprocity a system of reprisal, instead of a furtherance of juridical relations."-A. S. DeBustamente, quoted in Lorenzen, Cases on the Conflict of Laws, 15 .
}

The result in Hilton v. Guyot, I59 U. S. II3, indicates that the criticism is not wholly unjustifiable. 
wholesale adoption of foreign laws (with certain exceptions): and thus to lay a foundation for the hypothesis that the courts do not permit the foreign law to operate by exercising comity in the particular case, but that the permission having already been given by the comity of the nation, the courts are bound to allow the foreign law to operate within the forum.

According to this hypothesis, comity is nothing more than the reason why the state has tacitly adopted foreign law. There is an air of plausibility about the formula until it is tested by applying it to a case of first impression, when it becomes at once apparent that the court is not bound to assume the adoption of the particular foreign law in question, unless first satisfied that it is not repugnant to the policy of the forum. Since all judicial precedent is created by the decision of cases of first impression, it follows that so far as foreign law has already been "tacitly" adopted, it has been so adopted by the courts in the attempt to administer justice in cases to which no existing rule of decision was precisely applicable.

Professor Beale and Mr. Wharton, in explaining but not advocating the doctrine of comity, have attempted to justify Story's distinction between national comity and the comity of the courts. Professor Beale says :

"According to this theory, the territorial law alone has controlling force, but in some cases, out of comity or enlightered self-interest, the territorial sovereign allows the personal law to prevail. This, it will be seen, is only the reason for a sovereign's adopting a certain rule of law; the courts do not exercise comity and are as much bound by the legislative power as by any other portion of the law."12

One difficulty with this statement is that the legislative will cannot be manifested to the courts except by statute; then it is the statute which prevails, and not the personal law. Wharton falls a little deeper into the same difficulty: although affirming that the courts do not exercise comity in the particular case, he admits that the rule of comity has been established, in part, by judicial precedent.

"It is not the comity of the court in the particular case but the general comity of the sovereign as declared by legislation or judicial precedent, establishing a uniform ruling, which may properly be regarded as a basis of the recognition and application of a foreign law."13

Both of these explanations are inadequate because they refer to comity as if it were an extinct emotion of the sovereign which had already exhausted itself in shaping the law of the forum; and because they ignore the fact that the doctrine of comity must be dealt with in its

\footnotetext{
12 Beale, ro2.

13 Wharton (3d ed.) Ia.
} 
practical application as a living principle for determining whether foreign rights shall or shall not be enforced in a given case.

If it were possible to assume that all foreign laws, as soon as they became such, were automatically adopted by the state, then it might be said that the courts could not exercise comity in a given case. But the moment the necessary exception of laws repugnant to the policy of the forum is made, the question whether a foreign law has or has not been tacitly adopted-that is to say, the question whether it is or is not repugnant to the policy of the forum-is necessarily referred to the court in which the question arises. And assuming that the issue thus presented is a debatable one, it seems clear that the court cannot decide it without assuming authority to exercise or withhold the comity of the state, and thus exercising a discretion which, though judicial in form, is legislative in character.

Practically, the court does not ask itself whether the foreign law in question has been adopted by the state. It simply decides for itself whether or not the foreign law is so repugnant to the policy of the forum that it ought not to be allowed, ex comitate, to operate there. The actual result has been that the enforcement of foreign rights in this country depends on comity exercised by the courts, or, to put it more tersely, upon judicial discretion.

The latest compilations of current law recognizes the existence of this condition.

"Each sovereignty determines for itself the extent to which it will apply the doctrine of comity. And in the absence of legislative provision its exercise in admitting or restraining the application of the laws of another country must rest in sound judicial discretion, controlled by the circumstances of the case." 14

"Comity, being voluntary and not obligatory, rests in the discretion of the tribunals of the forum, governed by certain more or less widely
recognized rules."15

A few citations to the same effect are added in the notes, ${ }^{18}$ but no

${ }^{16}$ I2 Corp. Jur. $437-8$.

${ }^{15} 5$ R. C. L. 910.

18 "But, as the laws of foreign countries are not admitted ex proprio vigore, but only ex comitate, the judicial power will exercise a discretion with respect to the laws they may be called upon to sanction."-Parker, C.J., Blanchard $v$. Russell (1816) I3 Mass. I, 6.

"The exercise of comity in admitting or restraining the application of the laws of another country must rest on sound judicial discretion, dictated by the circumstances of the case."-Edgerly v. Bush (1880) 8x N. Y. 199, 204.

"Comity, being voluntary and not obligatory, cannot supersede all discretion on the subject."-Gooch v. Faucett (I898) I22 N. C. $270,272$.

"Courts of each state must, at least, in the absence of positive law, determine how far comity requires the enforcement of foreign contracts."-Flagg v. Baldwin (1884) 38 N. J. Eq. 219, 224.

"The extent to which comity will be extended being very much a matter of judicial policy to be determined within reasonable limitations by each state for itself."-International Harvester Co. v. McAdam (IgIo) I42 Wis. II4, IIg. 
more authoritative statement of the current American doctrine is needed than an excerpt from a recent opinion by Mr. Chief Justice White:

"It is elementary that the right to enforce a foreign contract in another foreign country could alone rest upon the general principles of comity. But elementary as is the rule of comity, it is equally rudimentary that an independent state under that principle will not lend the aid of its courts to enforce a contract founded upon a foreign law where to do so would be repugnant to good morals, would lead to disturbance and disorganization of the local municipal law, or, in other words, violate the public policy of the state where the enforcement of the foreign contract is sought. It is, moreover, axiomatic that the existence of the described conditions preventing the enforcement in a given case does not exclusively depend upon legislation, but may result from judicial consideration of the subject ...."17

This quotation is made at length because it happens to embody three closely related propositions generally accepted by our courts which, taken together, form a real stumbling-block in the path of our interstate jurisprudence. They are, first, that the enforcement of a foreign right involves the extra-territorial operation, within the forum, of the foreign law which created it. Second, that in the absence of legislation, judicial comity (which means judicial discretion) is the basis of the enforcement of foreign rights. Third, that the public policy of the forum may be violated by the enforcement of a vested right which has arisen out of a transaction carried to completion in another state.

The first point is not clearly brought out in words, but is necessarily involved in the doctrine of comity, which was invented to explain the extra-territorial operation of foreign law. The second is expressed in the statement that in the absence of legislation, the conditions preventing the enforcement of a foreign right (that is, the conditions under which comity will not be exercised) are to be determined by judicial consideration. The third is involved in the character of the action which was to recover a debt arising from the purchase and sale of cotton futures for the defendant's account, the underlying contract being valid in New York where it was made and performed.

Undoubtedly the "rudimentary" principle that courts will not enforce foreign contracts when to do so would violate the policy of the forum, is the commonly accepted doctrine in this country.

But the point to which attention is now directed is the underlying assumption that in certain cases the policy of the forum may be violated by enforcing a vested contractual right to recover damages, or a debt, simply because the policy of the forum differs from the policy of the state where the cause of action arose, in respect of some debatable question of internal policy, such as the propriety of permitting dealings in cotton futures, or speculations in stocks on margin, or stipula-

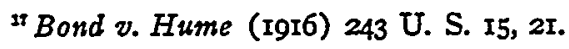


tions exempting telegraph companies from liability for negligence in the transmission and delivery of unrepeated telegrams, or in respect of any other of the many questions of internal policy concerning which the forty-eight states of this Union are not in unanimous agreement.

The same rule is applied to prevent the enforcement of vested rights acquired otherwise than by contract. "If the statute creating the right is against the policy of the law of the neighboring State, that is a sufficient reason for refusing to enforce the right there."18

Let us put aside for a moment the theory of the extra-territoriality of law, and examine this doctrine that the policy of the forum may be violated by the enforcement of a cause of action for money damages validly created by the law of another state.

We must admit that extreme cases might be imagined in which the mere enforcement of a foreign right would be an offense against good morals. But such cases cannot arise among the several states of the United States. Their differences relate to the minor morals of expediency, and to debatable questions of internal policy. It would be an intolerable affectation of superior virtue for the courts of one state to pretend that the mere enforcement of a right validly created by the law of a sister state "would be repugnant to good morals, would lead to disturbance and disorganization of the local municipal law," or would be of such evil example as to corrupt the jury or the public.

No doubt every court prefers the law of its own state, but as between this Union of states forming one nation, the only tolerable assumption must be that the laws of each state are well adapted to do justice and promote morality within their respective limits; and the full faith and credit clause of the Federal Constitution has embodied that assumption in the supreme law of the land. It seems clear that the mere enforcement of a cause of action which has arisen under the laws of a sister state cannot offend public morals.

What is it, then, which prevents the interstate enforcement of a very considerable class of state-created rights that are not only just, but ethically inoffensive? Not the policy of the forum alone, for the policy of a state cannot exist as such outside of its own limits. If the state of Texas, for example, should enact a statute making all contracts for the future sale and delivery of cotton illegal, it must necessarily be construed to apply only to contracts made, or to be performed in whole or in part, in Texas. Her sovereignty cannot be offended by a speculation in cotton futures entered into and carried out in New York. And for the same reason-to wit, that it does not purport to operate outside of the state,-a New York statute authorizing transactions in cotton futures could not properly be held contrary to the policy of Texas. The different internal policies of the two states cannot conflict,

${ }^{28}$ Howarth v. Lombard (1900) 570, 573. 
because neither intrudes upon the territory of the other. If we succeed in keeping the doctrine of extra-territoriality of law out of sight, this is self-evident.

Now, if we add to these considerations the proposition that by the common consent of mankind, rights and obligations arising out of a foreign transaction ought to be ascertained and enforced according to the law of the place where they arose, it is apparent that the policy of the forum cannot, with any regard for logic or general principles of justice, be said to be violated either by the enforcement of a vested right created by the law of a sister state, or by the fact that the law which created it differs, in respect of some debatable question of internal policy, from the corresponding law of the forum.

But the moment we inject the fiction of the extra-territorial operation of law, as law, into the discussion, the real reason for refusing to do justice in this class of cases appears. An entirely new question confronts the court which is quite independent of the merits of the controversy: is it consistent with the policy of the forum to permit the foreign law in question to operate there? Thus, if $A$. sues $B$. in the courts of Texas for a debt arising out of a transaction in cotton futures carried out in New York, the fiction that the court is asked to permit the law of New York to operate within the state of Texas requires a comparison of the laws of the two states to see whether the public policy of Texas will permit the New York law to operate there. So if A., as administrator, sues B. in a Connecticut court for the wrongful death of his decedent to recover the damages, to which he has become entitled under a Massachusetts statute, A.'s action may be defeated on the ground that "comity does not require that we enforce the statute of a foreign jurisdiction which is so manifestly contrary to the public policy of our law."19

Conversely, the fiction of the extra-territorial operation of the foreign law may result in the creation of a right which did not exist when the action was brought; and the argument in favor of creating a right which does not exist is just as logical as that in favor of refusing to enforce a right which does exist. Thus, in Fox v. Postal Telegraph $\mathrm{Co}^{20}$ a telegram was sent from New York to Chicago under a stipulation exempting the defendant from liability for negligence in transmission. The stipulation was valid in New York where made, and valid in Illinois where the negligence occurred. Yet when suit was brought in Wisconsin, where such stipulations were illegal, the court held that public policy would not permit the law of New York or of Illinois to operate in Wisconsin; and in order to prevent a sup-

${ }^{2}$ Cristilly v. Warner (19r3) 87 Conn. 46r, 466; Howarth v. Lombard (1900)

I75 Mass. 570, 573.

${ }^{20}$ (Ig09) 138 Wis. 648. 
posed violation of the policy of the forum, it created and enforced a right to damages to which the actual transaction had not given rise.

The manifest injustice (so far as private interests are concerned) of this large class of decisions is aggravated by the fact that the doctrine of the ex comitate extra-territorial operation of law, as law, is entirely discredited by modern scholarship. Even the editors of Story have long ago abandoned it. ${ }^{21} I$ think it may be said that no modern North American authority on the science of private international law advocates it. The distinction between the territorial law and the transitory right created by it is universally recognized by English and North American writers.

To sum it all up, the almost unbelievable condition of fact is that in one hundred and thirty years, this Union of states bound together into one nation "as members of one great political family," has not established a more satisfactory basis for the interstate enforcement of private rights than a rule of imperfect obligation, based upon a discredited fiction, which necessarily breeds inconsistency and conflict of decision, ${ }^{22}$ and in a large class of cases creates a purely imaginary conflict between the policy of the forum and the enforcement of just and ethically correct vested rights.

It must not be supposed that I am criticizing the courts. On the contrary, the defects pointed out are the necessary and logical consequences of a doctrine which was imposed on the courts of this country by the commanding influence of Story and of the Supreme Court of the United States. My object is to direct attention to the condition of fact in the hope that some effort may be made to better it.

Assuming that the thing to be desired is the uniform interstate enforcement of vested private rights, two possible directions suggest themselves in which progress toward that end may be made.

First, by a logically complete application of the full faith and credit

${ }^{21}$ Thus, Redfield (6th ed.) 36 says :

"The courts in referring to the law of the foreign state in order to give the proper force and interpretation to the contract or relation and the consequent duties and obligations, cannot be said to act from comity, any more than they could be said to refer to a dictionary of a foreign language from comity, when such reference is indispensable to the proper understanding of the terms in

Bigelow (8th ed.) 38 puts the same idea more compactly:

"In applying the French law, the court does not allow it to operate in America but only recognizes the fact that it did operate in France."

2 See, by way of illustration merely, the conflicting decisions relating to the Massachusetts variation of Lord Campbell's Act. Pro: Boston \& $M . R . R$. v. Hurd (I90I) I08 Fed. II6; Malloy v. American Hide and Leather Co. (I906) I48 Fed. 482; Fill v. Boston \& M. R. R. (I914) 77 N. H. I5I.

Contra: Adans v. Fitchburg R. R. (I894) 67 Vt 76; O’Reilly v. N. Y. \& N. E. R. R. (I889) I6 R. I. 388; Cristilly v. Warner (I913) 87 Conn. 46r. 
clause of the Constitution, based upon the principle that the essential nature and real foundation of a cause of action are not changed by recovering judgment on it..$^{23}$

Huntington v. Attrill ${ }^{24}$ holds that penal statutes in the international sense include only those which deal with offenses against the state; and by necessary implication it holds that causes of action based on judgments founded on statutes dealing with private rights and remedies are constitutionally enforceable, so far as the remedy is one which the courts of the forum can give. If the full faith and credit clause has any mandatory force, this must be so. Otherwise the judgments of courts of competent jurisdiction of one state would have no effect in another state, except as a matter of comity or judicial discretion. Take, for example, the case of Cristilly $v$. Warner, ${ }^{25}$ and suppose that the plaintiff administrator had caught the defendant in Massachusetts and obtained a judgment against him there before bringing his suit in Connecticut; would not our courts have been bound to give full faith and credit to the judgment?

If so, it must be because the several states have, by ratifying the Constitution, surrendered their sovereign right of refusing to "exercise comity" in the case of actions based on judgments of the courts of sister states. Surely the Constitution expresses the real and controlling "policy" of the states in this regard, and since the essential character and real foundation of a cause of action are not changed by recovering judgment on it, it cannot logically and reasonably be said that it is in accord with the policy of the forum to enforce a given cause of action after judgment has been recovered on it, and yet contrary to its policy to enforce the same cause of action before judgment has been recovered on it.

The evidential conclusiveness of the judgment, the fiction of the merger of the original cause of action, and the implied new promise, are of no consequence in controlling or evading the sovereign policy of a state. As pointed out in the cases cited, courts to which a foreign judgment is presented for affirmative action look through these technicalities and ascertain the essential character of the underlying cause of action.

\footnotetext{
s "The essential nature and real foundation of a cause of action are not changed by recovering judgment upon it; and the technical rules which regard the original claim as merged in the judgment, and the judgment as implying a promise to pay it, do not preclude a court, to which a judgment is presented for affirmative action, (while it cannot go behind the judgment for the purpose of examining into the validity of the claim,) from ascertaining whether the claim is really one of such a nature that the court is authorized to enforce it."Wisconsin v. Pelican Ins. Co. (1887) 127 U. S. 265, 292.

2 (1892) 146 U. S. 657, 67I; supra, n. 6.

s Supra, n. 19.
} 
In this connection it is interesting to note that $\mathrm{Mr}$. Chief Justice White, in his opinion in Bond v. Hume, ${ }^{28}$ refers, not once but twice, to what he significantly calls "the duty of the courts of that state under the Constitution to give effect to a contract validly made in another state." 27 These words have no apparent direct relation to the decision of the case, and it must be admitted that their suggestion of constitutional obligation is not easily reconciled with that part of the opinion already quoted. Nevertheless, they necessarily foreshadow the possible announcement of a rule of constitutional law which would conform our interstate jurisprudence to the fact of national unity.

The other possible way of accomplishing the desired result is by carrying Story's formula one step further than he did. In attempting to improve on the Dutch theory of comity, Story got so far as to assume the tacit adoption of foreign laws by the state, and thus to suggest that they operated thereafter as rules of municipal law. The suggestion was necessarily imperfect, because it could not be carried to its logical conclusion without abandoning the theory of the extraterritoriality of law. And that, Story did not have the courage to do. Consequently, the law of the forum on any given subject consisted, according to the Storyan formula, of the local law surrounded by an indeterminate number of foreign laws relating to the same subject. The local law operated continuously and generally upon local transactions, and the foreign laws operated intermittently and occasionally upon transactions carried on in other states. For all practical purposes the result was to engraft upon the general rule of the local law a number of specially applicable exceptions for particular cases. In the light of the present development of international jurisprudence, it is apparent that these exceptions might as well have been grouped together and their aggregate operation stated in the form of one general exception possessing the qualities of continuity and generality. For if the courts have power to assume the tacit adoption by the state of an indeterminate number of foreign laws (not repugnant to the policy of the forum), they also have power to assume the tacit adoption by the state of one general rule of municipal law to the effect that rights and obligations arising out of a foreign transaction should be ascertained and enforced (so far as their enforcement is not repugnant to the policy of the forum), according to the law of the state where they arose. ${ }^{28}$ No doubt the statement of the rule may be improved upon, but no doubt such is in substance the rule of

\footnotetext{
* Supra, n. I7.

"T The italics are those of the present, writer.

2s The occasional difficulty of determining situs is inherent, and is not increased or diminished by any form of stating the underlying rule of decision.
} 
civilization and right which our courts try to live up to, except when the fiction of the extra-territoriality of law compels a miscarriage of justice. Some of the reasons why the enforcement of vested rights created by the law of one state cannot reasonably be said to violate the internal policy of a sister state have been given. My suggestion is that the time has come when Story's formula ought to be restated so as to carry it to its logical conclusion, and at the same time to avoid the purely imaginary conflict between the enforcement of vested rights and the policy of the forum, a conflict which is a reproach to our interstate jurisprudence. 